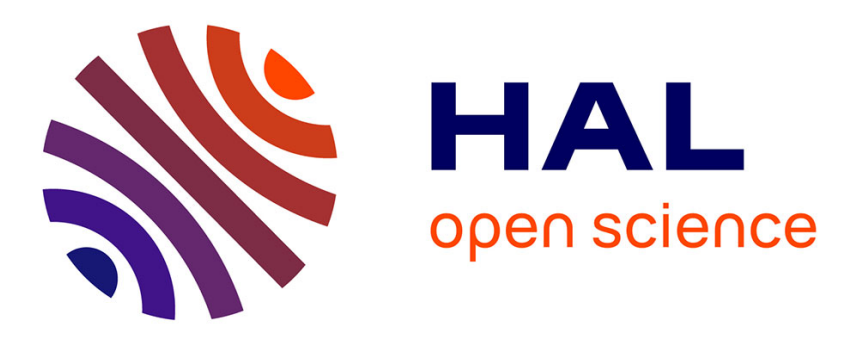

\title{
Expression of immunoregulatory genes in peripheral blood mononuclear cells of European wild boar immunized with BCG
}

José Manuel Pérez de La Lastra, Ruth C. Galindo, Christian Gortázar, Francisco Ruiz-Fons, Alicia Aranaz, José de La Fuente

\section{To cite this version:}

José Manuel Pérez de La Lastra, Ruth C. Galindo, Christian Gortázar, Francisco Ruiz-Fons, Alicia Aranaz, et al.. Expression of immunoregulatory genes in peripheral blood mononuclear cells of European wild boar immunized with BCG. Veterinary Microbiology, 2009, 134 (3-4), pp.334. 10.1016/j.vetmic.2008.08.026 . hal-00532471

\section{HAL Id: hal-00532471 \\ https://hal.science/hal-00532471}

Submitted on 4 Nov 2010

HAL is a multi-disciplinary open access archive for the deposit and dissemination of scientific research documents, whether they are published or not. The documents may come from teaching and research institutions in France or abroad, or from public or private research centers.
L'archive ouverte pluridisciplinaire HAL, est destinée au dépôt et à la diffusion de documents scientifiques de niveau recherche, publiés ou non, émanant des établissements d'enseignement et de recherche français ou étrangers, des laboratoires publics ou privés. 


\section{Accepted Manuscript}

Title: Expression of immunoregulatory genes in peripheral blood mononuclear cells of European wild boar immunized with BCG

Authors: José Manuel Pérez de la Lastra, Ruth C. Galindo, Christian Gortázar, Francisco Ruiz-Fons, Alicia Aranaz, José

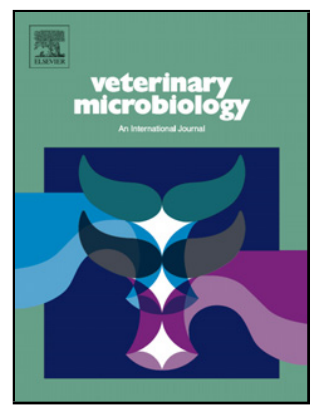
de la Fuente

PII:

S0378-1135(08)00355-6

DOI: doi:10.1016/j.vetmic.2008.08.026

Reference: VETMIC 4140

To appear in: $\quad$ VETMIC

Received date: $\quad$ 24-6-2008

Revised date: $\quad 19-8-2008$

Accepted date: $\quad$ 25-8-2008

Please cite this article as: de la Lastra, J.M.P., Galindo, R.C., Gortázar, C., Ruiz-Fons, F., Aranaz, A., de la Fuente, J., Expression of immunoregulatory genes in peripheral blood mononuclear cells of European wild boar immunized with BCG, Veterinary Microbiology (2007), doi:10.1016/j.vetmic.2008.08.026

This is a PDF file of an unedited manuscript that has been accepted for publication. As a service to our customers we are providing this early version of the manuscript. The manuscript will undergo copyediting, typesetting, and review of the resulting proof before it is published in its final form. Please note that during the production process errors may be discovered which could affect the content, and all legal disclaimers that apply to the journal pertain. 
Expression of immunoregulatory genes in peripheral blood mononuclear cells of European wild boar immunized with BCG

José Manuel Pérez de la Lastra ${ }^{1 \dagger *}$, Ruth C. Galindo ${ }^{1 *}$, Christian Gortázar ${ }^{1}$, Francisco Ruiz-Fons ${ }^{1}$, Alicia Aranaz ${ }^{3}$ and José de la Fuente ${ }^{1,2}$

${ }^{1}$ Instituto de Investigación en Recursos Cinegéticos, IREC (UCLM-CSIC-JCCM).

10 Ronda Toledo s/n, 13005 Ciudad Real, Spain

${ }^{2}$ Department of Veterinary Pathobiology, Center for Veterinary Health Sciences, Oklahoma State University, Stillwater, OK 74078, USA.

${ }^{3}$ Departamento de Sanidad Animal. Facultad de Veterinaria, Universidad Complutense de Madrid. Avenida Puerta de Hierro s/n, 28040 Madrid. Spain

15

*The first two authors contributed equally to this work.

${ }^{\dagger}$ Corresponding author: José Manuel Pérez de la Lastra (josemanuel.plastra@uclm.es)

20 Abbreviations: PBMC, peripheral blood mononuclear cells; Tb, tuberculous.

Keywords: wild boar, porcine, BCG, immunization, tuberculosis, signature, genomics, real-time RT-PCR. 


\section{Abstract}

The objective of this study was to analyze the expression of immunoregulatory genes in European wild boar (Sus scrofa) immunized with BCG. Eighteen immunoregulatory 5 genes were selected for expression analysis based on their role in host immune response during tuberculosis and/or for their association with resistance to bovine tuberculosis in European wild boar populations. Initially, mRNA levels were analyzed by quantitative real-time reverse transcription PCR (qRT-PCR) in spleen samples from Mycobacterium bovis infected $(\mathrm{N}=18)$ and uninfected $(\mathrm{N}=22)$ European wild boar. Statistical analysis of

10 qRT-PCR data revealed that four genes, complement component C3, IFN-gamma, IL-4 and RANTES were downregulated in infected animals $(\mathrm{P}<0.05)$. These genes were selected for analysis of mRNA levels in peripheral blood mononuclear cells (PBMC) from seven wild boar experimentally immunized with BCG and seven non-immunized controls. Blood was collected at 0, 5, 13 and 25 weeks post-immunization (wpi). The

15 mRNA levels of IFN-gamma and C3 showed a peak (>15 fold increase) at 5 wpi, whereas transcripts for RANTES and IL-4 showed a peak (>2 fold increase) at 13 wpi in BCG-immunized animals when compared to non-immunized controls. The pattern of expression of these genes over the time provides the first description of BCG specific immune response in European wild boar. These results provide new insights into the

20 molecular basis of wild boar response to M. bovis infection and BCG vaccination and may be used to monitor BCG vaccination in this species. 
Vet Microbiol

\section{Introduction}

The Mycobacterium bovis and closely related mycobacteria of the Mycobacterium tuberculosis complex that cause bovine tuberculosis (bTB) have an extensive host range

5 and may cause zoonotic TB (de Lisle et al., 2002; Gortazar et al., 2005; Neill et al., 2005). Despite efforts to eradicate bTB (Pollock et al., 2006), the disease has not been eradicated from many countries (Pavlik, 2006), partly because of the reservoir of $M$. bovis in wildlife (Corner, 2006; Naranjo et al., 2008). One potential tool for the management of disease in wildlife populations and to limit the spread of infection is

10 vaccination (Buddle et al., 2006). The European wild boar (Sus scrofa) is a major reservoir of M. bovis in some regions of Spain and vaccination of wild boar might prove necessary for the control of bTB in this country (Buddle et al., 2000; Naranjo et al., 2008).

During mycobacterial infection, a dynamic cross-talk occurs between the host and the

15 pathogen, in which they reciprocally influence their gene expression profiles (Gordon et al., 2001). The study of gene expression profiles in tissues from infected wild boar may be crucial for the understanding of the regulation of anti-mycobacterial immunity in this wildlife reservoir species. Recently, we demonstrated differential gene expression in tonsils and mandibular lymph nodes of infected and uninfected European wild boar

20 exposed to natural $M$. bovis infection and identified possible correlates of resistance to bTB in this species (Naranjo et al., 2006; Naranjo et al., 2007a; Naranjo et al., 2007b). Herein, we first analyzed the expression of immunoregulatory genes in spleen samples from naturally $M$. bovis-infected and uninfected European wild boar to select host immunoregulatory genes differentially regulated in response to bTB in this species.

25 Genes significantly downregulated in infected animals were selected for qRT-PCR analysis of mRNA levels in wild boar immunized with BCG. This study provides the 
first description of the BCG specific response in wild boar that may provide insights into the molecular basis of wild boar response to $M$. bovis infection and BCG vaccination and may be used to monitor BCG vaccination in this species.

\section{2. Materials and Methods}

\section{1. Wild boar and tissue samples}

Spleen fragments of approximately $2 \mathrm{~cm}^{3}$ were collected post mortem from adult $(\geq 1$ year old) hunter-harvested European wild boar and stored in liquid nitrogen for RNA extraction. Animals were sampled in hunting estates from Castilla-La Mancha, Spain.

10 Wild boars were classified as infected or uninfected based on the presence or absence, respectively of the following criteria: (1) the presence of lesions characteristic of bTB and (2) the identification of positive mycobacterial cultures and determination of $M$. bovis spoligotypes. According to these criteria, 18 wild boars were infected with $M$. bovis and 22 were used as uninfected controls.

\section{$15 \quad$ 2.2. Selection of immunoregulatory genes}

Immuoregulatory genes (Table 1) were selected based on their putative role during mycobacterial infection and/or for their association with resistance to bTB in European wild boar (Naranjo et al., 2006). The genes analyzed herein included Interferon gamma (IFN-gamma), Regulated on Activation, Normal T Expressed and Secreted cytokine,

20 also known as CCL5 (RANTES), superoxide dismutase-Mn type (SOD), vascular cell adhesion molecule 1 (VCAM-1), monocyte chemoattractant protein 1 (MCP-1), apolipoprotein A-I (APOA1), CXCL8 or interleukin 8 (IL-8), tumour necrosis factors alpha (TNF-alpha), interleukin-1 beta (IL-1 beta), methylmalonyl Coenzyme A mutase (MUT), complement component 3 (C3), interleukin-12 (IL-12), secreted

25 phosphoprotein 1 (SPP-1), granulocyte-macrophage colony-stimulating factor (GM- 
CSF), interleukin 4 (IL-4), fatty acid translocase/CD36 (CD36), interleukin 12 (IL-12), and vitamin D receptor (VDR).

\subsection{Immunization with BCG}

5 Fourteen wild boar ( 8 males and 6 females, <1 year old and 7-11 $\mathrm{Kg}$ weight at the beginning of the experiment) were captured in a bTB-free hunting state. Wild boars were placed together in an outdoor paddock, identified with an ear tag and allowed to acclimatise for one week. Seven animals were immunized at week 0 with a single intra dermal dose of $0.1 \mathrm{ml}$ containing $0.075 \mathrm{mg}$ of BCG Danish strain (Statens Serum

10 Institut, Copenhagen, Denmark). Control wild boars were not immunized. Blood was collected at $0,5,13$ and 25 weeks post-immunization (wpi). Blood was obtained by puncture of the right cranial vena cava and was collected in $10 \mathrm{ml}$ tubes with EDTA as anti-coagulant. Blood $(10 \mathrm{ml})$ was diluted 1:1 (vol:vol) with PBS (Sigma) and the mononuclear fraction containing PBMC was obtained by density gradient centrifugation

15 on Lymphoprep (Axis-Shield, Oslo, Norway).

At week 25, animals were euthanized by the captive bold method (Chambers \& Grandin, 2001), following European, National and University of Castilla-La Mancha Ethics Committee regulations. Wild boars were subjected to detailed post-mortem examination. In each animal, the bronchial, mediastinal, submandibular,

20 retropharyngeal, mesenteric and hepatic lymph nodes and lungs were examined macroscopically for bTB lesions and cultured on stonebrinks and Lowestein-Jensen media at $37^{\circ} \mathrm{C}$ for 8 weeks to detect mycobacteria of the $M$. tuberculosis complex (Costello et al., 1998). These analyses showed that the animals did not present bTBcompatible lesions and mycobacteria were not isolated from examined tissues, thus

25 demonstrating that the animals were bTB free at the end of the experiment.

\section{4. qRT-PCR analysis}


Total RNA was extracted from PBMC using the RNeasy kit (Qiagen, Izasa, Madrid, España) following manufacturers` recommendations. Total RNA from spleen samples was extracted using TRI-reagent (Sigma, Madrid, Spain) following manufacturers`

5 recommendations. The RNA yield and quality were assessed using the Experion Bioanalyzer (Bio-Rad, Madrid, Spain). Gene-specific oligonucleotide primers were designed using Primer3 software (Rozen and Skaletsky, 2000), synthesized (Bonsai Technologies, Madrid, Spain) and used for qRT-PCR (Table 1). qRT-PCR was performed in $25 \mu 1$ reaction volumes with $12.5 \mu 1$ SYBR Green iScript ${ }^{\circledR}$ (Bio-Rad).

10 Amplification conditions consisted of $95^{\circ} \mathrm{C}$ for $1 \mathrm{~min}$, followed by 40 cycles of $95^{\circ} \mathrm{C}$ for $15 \mathrm{~s}$ and $55^{\circ} \mathrm{C}$ for $60 \mathrm{~s}$. A dissociation curve was run at the end of qRT-PCR reaction to ensure that only one amplicon was formed and that the amplicon denatured consistently in the same temperature range for every sample (Ririe et al., 1997). All reactions were performed in duplicate. Oligonucleotide primers were used to amplify

15 the cyclophilin gene transcript as a control gene to normalize expression data (Meadus, 2003). Control reactions were performed using the same procedures, but without RT to control for DNA contamination in the RNA preparations and without RNA added to control contamination of the PCR reaction. Results were recorded as relative gene expression changes after normalizing for cyclophilin gene expression using the $2-\Delta \Delta \mathrm{Ct}$

20 method (Livak and Schmittgen, 2001). Briefly, the relative abundance of each mRNA transcript was calculated as the ratio of the value from BCG-vaccinated animals to the value from controls after cyclophilin correction for each of the four time points, producing a fold change value. In all cases, the mean of the duplicate values was used and data for vaccinated/control samples were compared using the Student's t-test $25 \quad(\mathrm{P}=0.05)$.

\subsection{Determination of serum IFN-gamma levels}


Blood was collected from wild boar and serum separated and stored at $-20{ }^{\circ} \mathrm{C}$. The serum concentration of IFN-gamma was determined using a quantitative ELISA (Pierce Endogen, Rockford, IL, USA) following manufacturer's recommendations.

\section{3. Results and Discussion}

The objective of the experiments described herein was to test whether vaccination of wild boar with BCG induces immunization-specific changes in gene expression. In addition, we wanted to investigate time-dependent gene expression changes over the period of immunization.

10 Prior to the analysis of the gene expression profiles in animals vaccinated with BCG, a study was designed to examine immunoregulatory gene expression profile in spleen samples from naturally $M$. bovis-infected and uninfected wild boar to find genes that are significantly downregulated in response to infection and thus are potentially being manipulated by the pathogen to establish infection. The expression of these genes in

15 wild boar vaccinated with BCG may reflect BCG-specific changes in gene expression that are different from those observed in animals naturally infected with $M$. bovis and could be used to monitor the immune response in BCG-vaccinated wild boar.

The work with wildlife species is difficult but allows the analysis of gene expression in naturally infected individuals (Naranjo et al., 2006). One disadvantage of working with

20 wild boar is that fresh blood is not always available in hunted animals. Therefore, we considered the spleen as the tissue sample of choice for the study of gene expression profile in response to mycobacterial infection in hunter-killed wild boar. In fact, it has been reported that the expression of cytokine genes such as IFN-gamma is similarly elevated after mycobacterial infection in PBMC and spleen cells of animal models of

25 TB (Kawahara et al., 2002). 
Statistical analysis of the normalized gene expression data in naturally $M$. bovis infected and uninfected wild boar revealed that 4 of 18 genes analyzed, C3, IFN-gamma, IL-4 and RANTES were downregulated in M. bovis-infected wild boar $(\mathrm{P}<0.05)$ (Fig. 1). The

5 genes differentially downregulated in infected wild boar were selected to investigate the host response to BCG immunization. Vaccination with BCG did not produce adverse reactions in wild boar as it has been reported in humans and domestic and wild animals (Murphy et al., 2008). Total RNA was extracted from PBMC of seven BCG-immunized and seven non-immunized control animals and used for transcriptional profiling. The

10 mRNA transcripts for IFN-gamma and C3 were significantly upregulated at 5 wpi only with over 15-fold increase in immunized animals (Fig. 2). In contrast, the mRNA transcripts for IL-4 and RANTES were significantly upregulated in BCG-immunized wild boar with over 2-fold increase at 13 wpi only (Fig. 2).

IFN-gamma is known to play a major role in macrophage activation and inflammation

15 (Koul et al., 2004). The changes in IFN-gamma gene expression in BCG-vaccinated animals (Fig. 2) were opposite to those observed in naturally M. bovis-infected versus uninfected wild boar (Fig. 1). However, these results are congruent with the reported increase in IFN-gamma expression during early stages of mycobacterial infection in humans, laboratory and farm animals and cultured macrophages (McMurray et al.,

20 2005) and after BCG vaccination of guinea pigs (Tree et al., 2006). Moreover, serum IFN-gamma concentrations were consistent with mRNA levels in naturally M. bovisinfected and BCG-vaccinated wild boar (Table 2).

IL-4 is a key regulator of humoral and adaptive immunity and inhibits the production of proinflammatory cytokines (Howard and Paul, 1982). RANTES is a proinflammatory

25 chemokine that plays an active role in recruiting leukocytes into inflammatory sites and also induces the proliferation and activation of certain natural-killer (NK) cells to form 
CHAK (CC-Chemokine-activated killer) cells (Maghazachi et al., 1996). RANTES is induced by M. tuberculosis in mouse and human macrophages (Ehrt et al., 2001; Ragno et al., 2001) and in mouse lungs after aerogenic infection (Keller et al., 2006). RANTES

5 is also weakly induced in BCG vaccinated guinea pigs (Tree et al., 2006). The overexpression of IL-4 and RANTES in BCG-vaccinated wild boar may result from an adjuvant effect of the mycobacteria in the BCG vaccine that causes a rapid entry of macrophages, lymphocytes, granulocytes, and probably dendritic cells into local sites of antigen deposition (Sugisaki et al., 1998).

10 Although it is generally recognized that humoral immunity is not important for the control of TB (Raja, 2004), IL-4 induced antibody response against $M$. bovis may be important for bTB control in wild boar and may be used for disease surveillance and treatment monitoring (Lyashchenko et al., 2007; Lyashchenko et al., 2006; Naranjo et al., 2007a; Waters et al., 2006). In contrast, the increase in IL-4 levels in humans

15 correlates with disease severity (Seah and Rook, 2001), a fact that may underline the existence of host-specific responses to mycobacterial infection that vary between species (Naranjo et al., 2007a).

This study describes the first attempt to use real-time qRT-PCR to investigate the host response to BCG immunization in wild boar. The balance between host genes

20 upregulated and downregulated in response to mycobacterial infection may be key determinants for disease progression. The results reported herein provide new insights on the expression of immunoregulatory genes that are integral to the host response to $M$. bovis in wild boar.

The vaccination of wild boar with BCG offers an alternative for control of bTB (Buddle

25 et al., 2000). However, several issues need to be addressed before introducing wild boar vaccination into practice. These issues include the design of oral immunization 
formulations and strategies and the assessment of possible vaccination drawbacks such as environmental impact and potential interference with tuberculin skin testing in cattle and farmed deer. Furthermore, whether wild boars vaccinated with BCG are protected 5 against bTB is unknown and falls outside the scope of this paper. However, gene expression profile in vaccinated animals showed BCG-specific responses that are different from those observed in naturally M. bovis-infected wild boar and may be used to monitor BCG vaccination during experimental vaccine studies in this species.

\section{Acknowledgements}

This work was supported by projects Control of Tuberculosis in Wildlife of Grupo Santander and Fundación Marcelino Botín to CG and JF, AGL2005-07401 of Ministerio de Educación y Ciencia (MEC), INIA project FAU 2006-00017 and FEDER (Spain). R.C. Galindo was funded by MEC, Spain. 


\section{Legends to Figures}

Figure 1. Quantitative gene expression analysis in spleen samples of M. bovis-infected and uninfected European wild boar using qRT-PCR analysis. Three experimental

5 replicates were done for each analysis with similar results. Amplification efficiencies were validated and normalized against S. scrofa cyclophilin (GenBank accession number AY008846). Bars show uninfected to infected average \pm S.D. mRNA ratios. Asterisks (*) indicate significant differences in mRNA levels between uninfected and infected animals $(P<0.05$, Student's $t$-test $)$.

10 Figure 2. Quantitative C3, IFN-gamma, IL-4 and RANTES gene expression analysis in PBMC of European wild boars immunized with BCG and controls using qRT-PCR. Results were recorded as the ratio of immunized to non-immunized after normalisation for cyclophilin gene expression using the $2-\Delta \Delta \mathrm{Ct}$ method for each of the four time points $(0,5,13$ and $25 \mathrm{wpi})$. In all cases, the mean of duplicate values was used and 15 data was compared between immunized and control animals by Student`s t-test $(* \mathrm{P}<0.05)$. Circles show average $\pm \mathrm{SD}$. 


\section{References}

Buddle, B.M., Skinner, M.A., Chambers, M.A., 2000, Immunological approaches to the control of tuberculosis in wildlife reservoirs. Vet Immunol Immunopathol 74, 116.

Buddle, B.M., Wedlock, D.N., Denis, M., 2006, Progress in the development of tuberculosis vaccines for cattle and wildlife. Vet Microbiol 112, 191-200.

Corner, L.A., 2006, The role of wild animal populations in the epidemiology of tuberculosis in domestic animals: how to assess the risk. Vet Microbiol 112, 303-312.

Costello, E., Doherty, M.L., Monaghan, M.L., Quigley, F.C., O'Reilly, P.F., 1998, A study of cattle-to-cattle transmission of Mycobacterium bovis infection. Vet $\mathbf{J}$ $155,245-250$.

de Lisle, G.W., Bengis, R.G., Schmitt, S.M., O'Brien, D.J., 2002, Tuberculosis in freeranging wildlife: detection, diagnosis and management. Rev Sci Tech 21, 317334.

Ehrt, S., Schnappinger, D., Bekiranov, S., Drenkow, J., Shi, S., Gingeras, T.R., Gaasterland, T., Schoolnik, G., Nathan, C., 2001, Reprogramming of the macrophage transcriptome in response to interferon-gamma and Mycobacterium tuberculosis: signaling roles of nitric oxide synthase-2 and phagocyte oxidase. J Exp Med 194, 1123-1140.

Gordon, S.V., Eiglmeier, K., Garnier, T., Brosch, R., Parkhill, J., Barrell, B., Cole, S.T., Hewinson, R.G., 2001, Genomics of Mycobacterium bovis. Tuberculosis (Edinb) 81, 157-163.

Gortazar, C., Vicente, J., Samper, S., Garrido, J.M., Fernandez-De-Mera, I.G., Gavin, P., Juste, R.A., Martin, C., Acevedo, P., De La Puente, M., Hofle, U., 2005, Molecular characterization of Mycobacterium tuberculosis complex isolates from wild ungulates in south-central Spain. Vet Res 36, 43-52.

Howard, M., Paul, W.E., 1982, Interleukins for B lymphocytes. Lymphokine Res 1, 1-4.

Kawahara, M., Nakasone, T., Honda, M., 2002, Dynamics of gamma interferon, interleukin-12 (IL-12), IL-10, and transforming growth factor beta mRNA expression in primary Mycobacterium bovis BCG infection in guinea pigs measured by a real-time fluorogenic reverse transcription-PCR assay. Infect Immun 70, 6614-6620.

35 Keller, C., Hoffmann, R., Lang, R., Brandau, S., Hermann, C., Ehlers, S., 2006, Genetically determined susceptibility to tuberculosis in mice causally involves accelerated and enhanced recruitment of granulocytes. Infect Immun 74, 42954309.

Koul, A., Herget, T., Klebl, B., Ullrich, A., 2004, Interplay between mycobacteria and host signalling pathways. Nat Rev Microbiol 2, 189-202.

Livak, K.J., Schmittgen, T.D., 2001, Analysis of relative gene expression data using real-time quantitative PCR and the 2(-Delta Delta C(T)) Method. Methods 25, 402-408.

Lyashchenko, K.P., Greenwald, R., Esfandiari, J., Meylan, M., Burri, I.H., Zanolari, P., 2007, Antibody responses in New World camelids with tuberculosis caused by Mycobacterium microti. Vet Microbiol 125, 265-273.

Lyashchenko, K.P., Greenwald, R., Esfandiari, J., Olsen, J.H., Ball, R., Dumonceaux, G., Dunker, F., Buckley, C., Richard, M., Murray, S., Payeur, J.B., Andersen, P., Pollock, J.M., Mikota, S., Miller, M., Sofranko, D., Waters, W.R., 2006, Tuberculosis in elephants: antibody responses to defined antigens of 
Mycobacterium tuberculosis, potential for early diagnosis, and monitoring of treatment. Clin Vaccine Immunol 13, 722-732.

Maghazachi, A.A., Al-Aoukaty, A., Schall, T.J., 1996, CC chemokines induce the

5

10 generation of killer cells from CD56+ cells. Eur J Immunol 26, 315-319.

McMurray, D.N., Allen, S.S., Jeevan, A., Lasco, T., Cho, H., Skwor, T., Yamamoto, T., McFarland, C., Yoshimura, T., 2005, Vaccine-induced cytokine responses in a guinea pig model of pulmonary tuberculosis. Tuberculosis (Edinb) 85, 295-301.

Meadus, W.J., 2003, A semi-quantitative RT-PCR method to measure the in vivo effect of dietary conjugated linoleic acid on porcine muscle PPAR gene expression. Biol Proced Online 5, 20-28.

Murphy, D., Corner, L.A., Gormley, E., 2008, Adverse reactions to Mycobacterium bovis bacille Calmette-Guerin (BCG) vaccination against tuberculosis in humans, veterinary animals and wildlife species. Tuberculosis (Edinb).

Naranjo, V., Gortazar, C., Vicente, J., de la Fuente, J., 2008, Evidence of the role of European wild boar as a reservoir of Mycobacterium tuberculosis complex. Vet Microbiol 127, 1-9.

Naranjo, V., Gortazar, C., Villar, M., de la Fuente, J., 2007a, Comparative genomics and proteomics to study tissue-specific response and function in natural Mycobacterium bovis infections. Anim Health Res Rev 8, 81-88.

Naranjo, V., Hofle, U., Vicente, J., Martin, M.P., Ruiz-Fons, F., Gortazar, C., Kocan, K.M., de la Fuente, J., 2006, Genes differentially expressed in oropharyngeal tonsils and mandibular lymph nodes of tuberculous and nontuberculous European wild boars naturally exposed to Mycobacterium bovis. FEMS Immunol Med Microbiol 46, 298-312.

Naranjo, V., Villar, M., Martin-Hernando, M.P., Vidal, D., Hofle, U., Gortazar, C., Kocan, K.M., Vazquez, J., de la Fuente, J., 2007b, Proteomic and transcriptomic analyses of differential stress/inflammatory responses in mandibular lymph nodes and oropharyngeal tonsils of European wild boars naturally infected with Mycobacterium bovis. Proteomics 7, 220-231.

Neill, S.D., Skuce, R.A., Pollock, J.M., 2005, Tuberculosis--new light from an old window. J Appl Microbiol 98, 1261-1269.

Pavlik, I., 2006, The experience of new European Union Member States concerning the control of bovine tuberculosis. Vet Microbiol 112, 221-230.

Pollock, J.M., Rodgers, J.D., Welsh, M.D., McNair, J., 2006, Pathogenesis of bovine tuberculosis: the role of experimental models of infection. Vet Microbiol 112, 141-150.

Ragno, S., Romano, M., Howell, S., Pappin, D.J., Jenner, P.J., Colston, M.J., 2001, Changes in gene expression in macrophages infected with Mycobacterium tuberculosis: a combined transcriptomic and proteomic approach. Immunology 104, 99-108.

Raja, A., 2004, Immunology of tuberculosis. Indian J Med Res 120, 213-232.

Ririe, K.M., Rasmussen, R.P., Wittwer, C.T., 1997, Product differentiation by analysis of DNA melting curves during the polymerase chain reaction. Anal Biochem 245, 154-160.

Rozen, S., Skaletsky, H., 2000, Primer3 on the WWW for general users and for biologist programmers. Methods Mol Biol 132, 365-386.

Seah, G.T., Rook, G.A., 2001, High levels of mRNA encoding IL-4 in unstimulated peripheral blood mononuclear cells from tuberculosis patients revealed by quantitative nested reverse transcriptase-polymerase chain reaction; correlations with serum IgE levels. Scand J Infect Dis 33, 106-109. 
Sugisaki, K., Dannenberg, A.M., Jr., Abe, Y., Tsuruta, J., Su, W.J., Said, W., Feng, L., Yoshimura, T., Converse, P.J., Mounts, P., 1998, Nonspecific and immunespecific up-regulation of cytokines in rabbit dermal tuberculous (BCG) lesions. $\mathrm{J}$ Leukoc Biol 63, 440-450.

Tree, J.A., Elmore, M.J., Javed, S., Williams, A., Marsh, P.D., 2006, Development of a guinea pig immune response-related microarray and its use to define the host response following Mycobacterium bovis BCG vaccination. Infect Immun 74, 1436-1441.

10 Waters, W.R., Palmer, M.V., Thacker, T.C., Bannantine, J.P., Vordermeier, H.M., Hewinson, R.G., Greenwald, R., Esfandiari, J., McNair, J., Pollock, J.M., Andersen, P., Lyashchenko, K.P., 2006, Early antibody responses to experimental Mycobacterium bovis infection of cattle. Clin Vaccine Immunol $13,648-654$. 


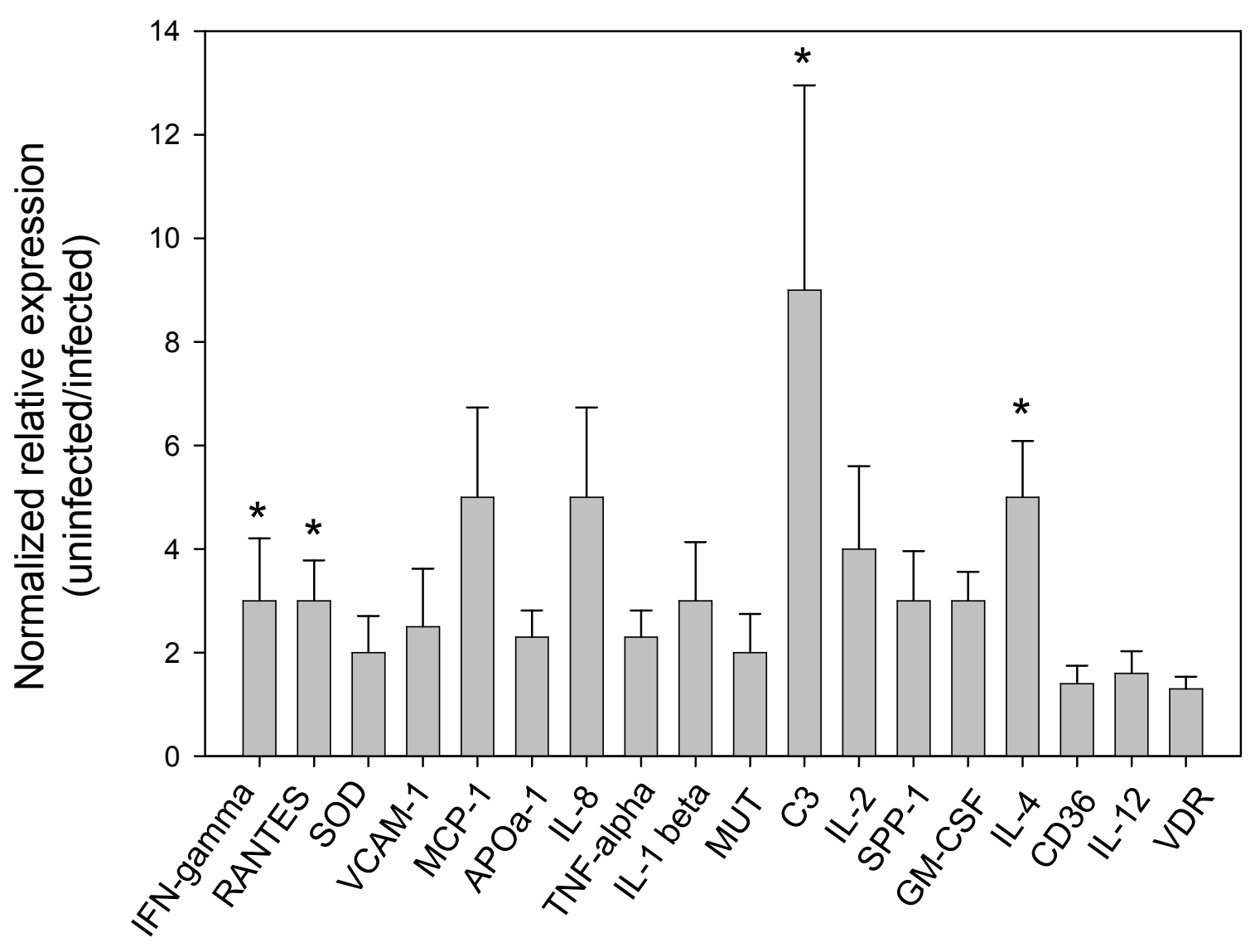

Figure 1 
RANTES

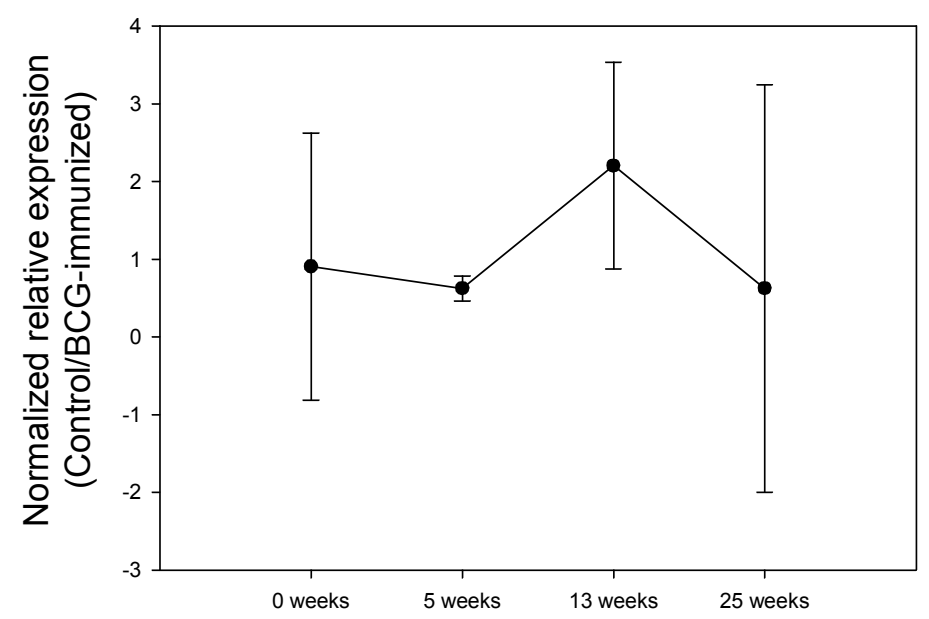

IFN-gamma

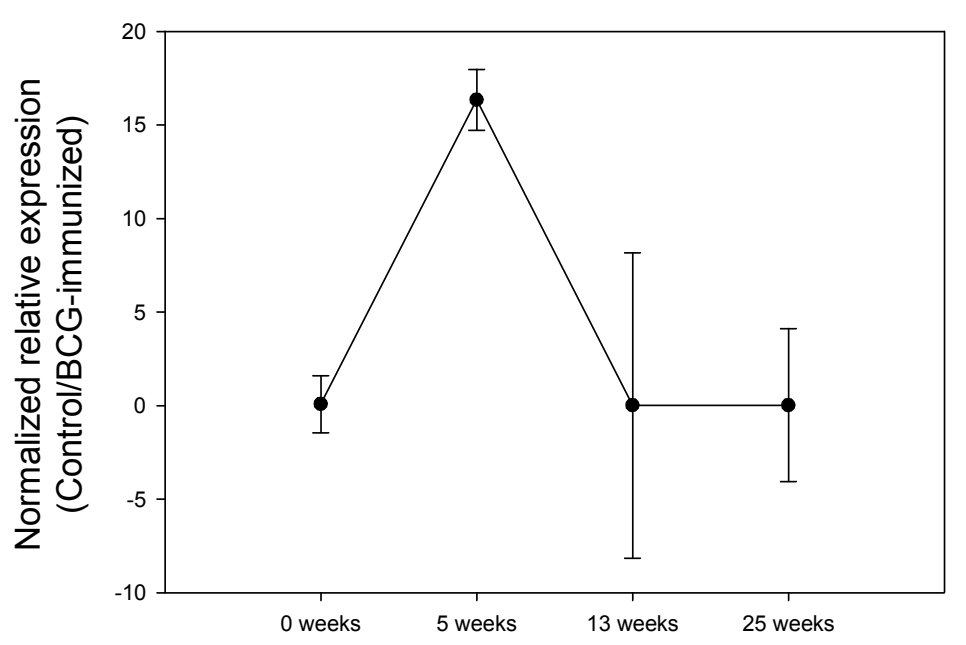

C3

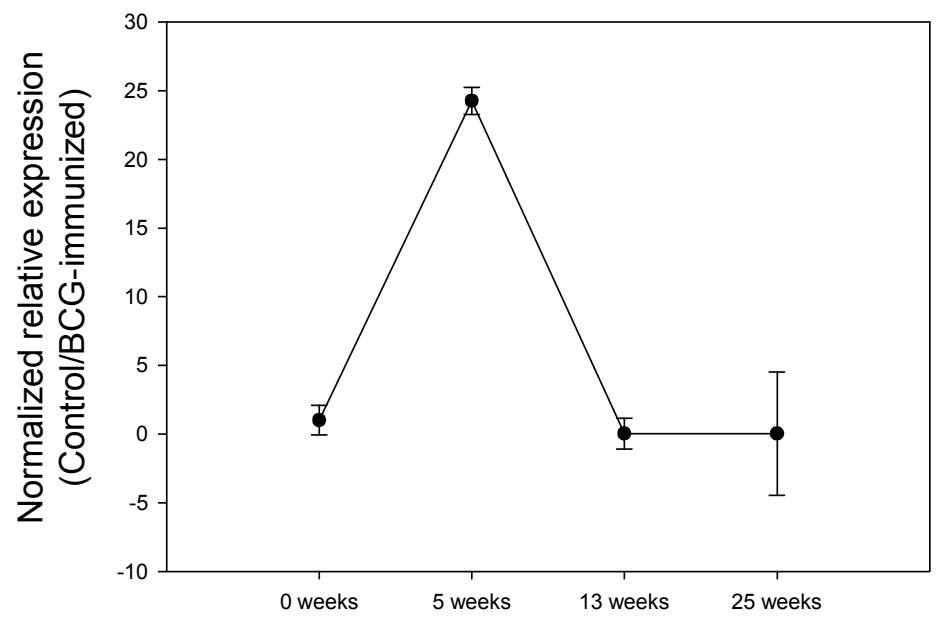

IL-4

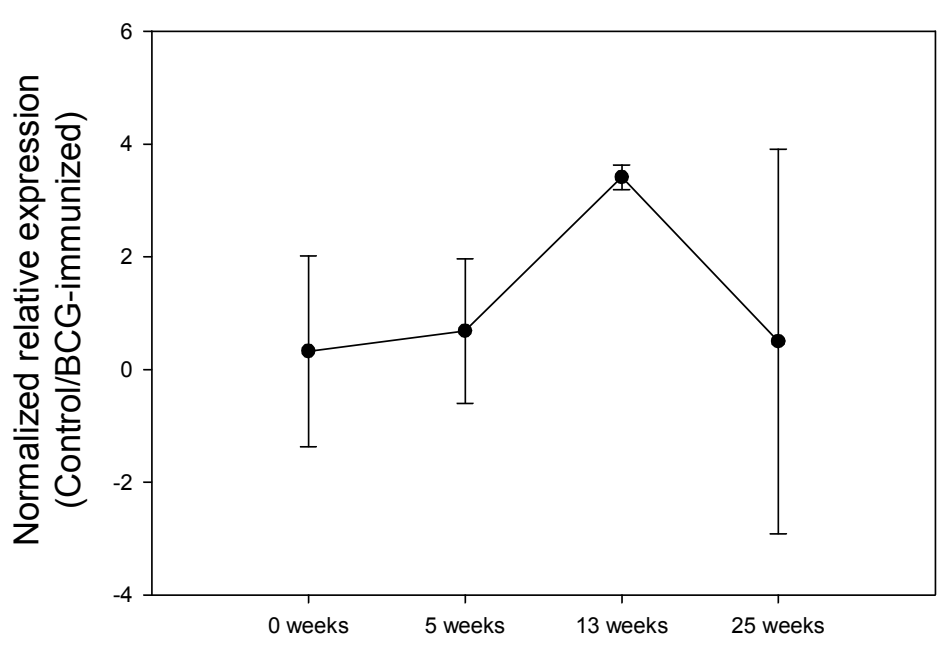

Figure 2 


\section{Table 1. Genes and oligosucleotides used for real time RT-PCR analysis}

\begin{tabular}{|l|l|l|l|}
\hline $\begin{array}{l}\text { Gene } \\
\text { description }\end{array}$ & $\begin{array}{l}\text { Accesion } \\
\text { number }\end{array}$ & Name and Sequence of primers & $\begin{array}{l}\text { Size of } \\
\text { product }\end{array}$ \\
\hline IL-1beta & NM_214055 & $\begin{array}{l}\text { SsIL1beta-L ccaagagggacatggagaa } \\
\text { SsIL1beta-R ttatatcttggcggccttt }\end{array}$ & 160 \\
\hline RANTES & AJ583704 & $\begin{array}{l}\text { SsRANTES-L tgctgctttgcctacagcta } \\
\text { SsRANTES-R ggcggttcttctggtgata }\end{array}$ & 233 \\
\hline TNFalfa & X54859 & $\begin{array}{l}\text { SsTNFalfa-L ccaccaacgttttcctcact } \\
\text { SsTNFalfa-R ccaaaatagacctgcccaga }\end{array}$ & 247 \\
\hline IL-8 & AB057440 & $\begin{array}{l}\text { SsIL8-L tggcagtttcctgctttct } \\
\text { SsIL8-R cagtggggtccactctcaat }\end{array}$ & 154 \\
\hline MCP-1 & NM_214214 & $\begin{array}{l}\text { SsMCP1-L tctcagtcactgctgcta } \\
\text { SsMCP1-R tccaggtggcttatggagtc }\end{array}$ & 185 \\
\hline IL-12 & L35765 & $\begin{array}{l}\text { SsIL12-L cctccaaactagcgacctca } \\
\text { SsIL12-R ctgagatggtccaggtggtt }\end{array}$ & 246 \\
\hline IFNgamma & DQ913893 & $\begin{array}{l}\text { SsIFNg-L ttcagctttgcgtgactttg } \\
\text { SsIFNg-R tccttgaatggctggtta }\end{array}$ & 201 \\
\hline IL-2 & NM_214123 & $\begin{array}{l}\text { SsIL4-L tctcacctccaactgatcc } \\
\text { SsIL4-R aaggttccttctccgtcgt }\end{array}$ & 156 \\
\hline GM-CSF & NQ_213861 & $\begin{array}{l}\text { SsIL2-L caaacggtgcacctacttca } \\
\text { SsIL2-R cctgcttgggcatgtaaaat }\end{array}$ & 156 \\
\hline CD36 & DQ192230 & $\begin{array}{l}\text { SsGMCSF-L gcagcctcactaggctcaag } \\
\text { SsGMCSF-R caaaggggatggtgaaaaga }\end{array}$ & $\begin{array}{l}\text { SsCD36-L cggttgcaggtcaacctatt } \\
\text { SsCD36-R tgatttctaccaggccaagg }\end{array}$ \\
\hline MUT & NM_214405 & $\begin{array}{l}\text { SsMUT-L gtttgccaacggtgaaaagt } \\
\text { SsMUT-R aatgagcttcaaggcagcat }\end{array}$ & 246 \\
\hline C3 & NM_214009 & SsC3-L acaaattgacccagcgtagg & 184 \\
\hline
\end{tabular}




\begin{tabular}{|l|l|l|l|}
\hline & & SsC3-R gcacgtccttgctgtactga & 165 \\
\hline SPP1 & NM_214023 & $\begin{array}{l}\text { SsSPP1-L cttggacagccaagagaagg } \\
\text { SsSPP1-R tggctgacttgggatttc }\end{array}$ & 234 \\
\hline APO A1 & NM_214398 & $\begin{array}{l}\text { SsAPOa1-L cgatcaaagacagtggcaga } \\
\text { SsAPOa1-R gctgcaccttcttcttcacc }\end{array}$ & 197 \\
\hline Mn-SOD & X64057 & $\begin{array}{l}\text { SsSOD-L cgctgaaaagggtgatgtt } \\
\text { SsSOD-R agcggtcaacttctcttga }\end{array}$ & 189 \\
\hline VDR & NM_213891 & $\begin{array}{l}\text { SsVCAM1-L atccaagctgctccaaaaga } \\
\text { SsVCAM1-R ggcctgtggatggtatatg }\end{array}$ & 194 \\
\hline Cyclophilin & AY008846 & $\begin{array}{l}\text { SsVDR-L acctggatctgagcgaagaa } \\
\text { SsVDR-R gatggcacttgacttcagca }\end{array}$ & $\begin{array}{l}\text { SsCyclophilin-L agcactggggagaaaggatt } \\
\text { SsCyclophilin-R cttggcagtgcaaatgaaaa }\end{array}$ \\
\hline
\end{tabular}


Table 2. IFN-gamma serum levels in wild boar uninfected and naturally infected with M. bovis and in BCG-immunized and control animals.

\begin{tabular}{|c|c|c|c|c|}
\hline \multicolumn{5}{|c|}{ IFN-gamma serum levels in wild boar (ng/ml) } \\
\hline \multicolumn{5}{|c|}{ Uninfected and naturally infected with $M$. bovis } \\
\hline & Mean \pm SD & & & \\
\hline Infected & $2.7 \pm 1.0$ & & & \\
\hline Uninfected & $3.0 \pm 1.5$ & & & \\
\hline \multicolumn{5}{|c|}{ BCG-immunized and controls } \\
\hline & 5 wpi & 13 wpi & 25 wpi & 8 \\
\hline & Mean \pm SD & Mean \pm SD & Mean \pm SD & \\
\hline Immunized & $3.2 \pm 0.7$ & $1.8 \pm 0.4$ & $1.5 \pm 0.2$ & \\
\hline Control & $2.7 \pm 0.6$ & $1.8 \pm 0.5$ & $1.8 \pm 1.0$ & \\
\hline
\end{tabular}

5

The concentration of serum IFN-gamma $(\mathrm{ng} / \mathrm{ml})$ was determined by a quantitative ELISA (Pierce Endogen, Rockford, IL, USA) following manufacturer's recommendations. 